\title{
REGULATORY ROLLBACKS IN THE AMAZON RAINFOREST: A NUANCED LOOK INTO THE EFFECTS OF ENVIRONMENTAL VICTIMIZATION
}

\author{
Eduardo Saad-Diniz and João Victor Gianecchini
}

\begin{abstract}
Since the beginning of Jair Bolsonaro's presidential mandate, existing Brazilian environmental regulations started being rolled back to benefit a small, but powerful, Brazilian bourgeoise, the so-called "Brazilian agribusiness." The process of deregulation in Brazil (regulatory rollback) is responsible for significant environmental and social harm, which affects largely marginalized peoples and indigenous communities in the Brazilian Amazon rainforest. It is also responsible for operating, and maintaining, dynamics of social inclusion and exclusion which are deepening the democratic deficit in Brazil, which is here denominated as the "mechanisms of environmental victimization." To demonstrate the Brazilian regulatory rollback the authors analyse legislative and regulatory amendments since the beginning of Jair Bolsonaro's mandate. Through this analysis, the authors seek to demonstrate how the symbiosis between state and corporate interests can promote significant social and environmental victimization.
\end{abstract}

Keywords: regulatory rollback; Brazilian Amazon rainforest; environmental victimization; green criminology

\section{Introduction}

One of the greatest challenges to the exercise of social control over harmful corporate behaviour is the cultivation of consistent and commensurate legal instruments, enforced through well-resourced and politically supported regulatory agencies (Laufer 2008; Simpson 2002; Braithwaite 2020; Clinard and Yeager 2001; Siegel et al. 2020). This is particularly the case for Brazil.

Environmental harm causation and social and environmental victimization are happening systematically in Brazil, but they are not being countered by sufficient responses, as accountability for corporate crimes and offences remains a major challenge in a political regime still impacted by a significant colonial heritage.

In particular, corporate criminal liability and the administrative sanctioning of corporations in Brazil is diminished by a political environment marked by

Authors: University of São Paulo, Brazil. Research granted by FAPESP. Process number: 2020/09148-4.

Produced and distributed by Pluto Journals www.plutojournals.com/scj/ 
intensive lobbying, in addition to state and regulatory capture practices. These dynamics undermine legislative efforts for developing a better framework of social control, and accountability for corporate wrongdoing.

Compounding matters, the Brazilian criminal justice system is still focused on prosecuting street crimes, while corporate harms remain largely unchallenged. There has not been any meaningful imposition of punishment for corporations implicated in serious wrongdoing (Saad-Diniz 2018: 547-79; 2019b) The Brazilian criminal justice system instead concentrates on individual accountability, despite the fact corporate criminology has already shown that the attribution of individual liability for corporate crimes does not have any impact on ethical behaviour in companies (Braithwaite and Fisse 1993: 6-46)

Nevertheless, in the current Brazilian scenario, it is necessary to take a few steps back to comprehend the whole problem involving corporate activity and its consequences for the stakeholders, victims and society in general. The deepening of contemporary corporate violence is not a contingent factor. On the one hand, it reflects the maturity of corporate initiatives designed to deepen its influence on the state's regulatory policy. On the other, it maintains the authoritarian corporate dynamics developed since the Brazilian colonialist system. The consequence is the reproduction and deepening of social and environmental victimization, leading to a greater impact on the democratic deficit in Brazil.

This essay aims, thus, to explore the links between environmental victimization in developing economies and the mechanisms responsible for producing the damage in those societies. To fulfil this objective, the authors have conducted a case study of the Brazilian framework regarding environmental victimization. It begins with a historical overview in which the development of these mechanisms is established. Then, a literature review is presented to capture the essence of environmental harm reproduction and the scholarly advances in the view of green criminology. Third, the regulatory rollback in Brazil is outlined, which provides a basis for conducting the analysis of environmental harms, as well as the social and economic victimization of minorities. The case study's concluding remarks call for the development of an agenda centred in challenging the mechanisms of environmental victimization, through the enhancement of environmental policies, and the turn of the current regulatory movement towards an evidence-based approach which ensures the preservation of Brazil's ecological heritage, and the promotion of the welfare of the Amazon local populations.

\section{Historical Mechanisms of Environmental Victimization}

With mercantilism (merchant capitalism), the countries colonized by the European metropolises produced commodities for export using slave labour and causing 
environmental destruction. Within this logic of production, European countries, considered as metropolises of the "Old Regime," exploited marginal economies to fill the production gaps of their countries and to promote the strategic development of their economies. As soon as the transition from merchant to industrial capitalism took place, amidst the development of the European Industrial Revolution, pressures increased for the reduction of production costs, which in the colonies meant the intensification of labour exploitation and environmental destruction (Novais 1989; Alencastro 2000).

Historical analysis reveals a continuum between the origins of the colonial productive system and Brazilian commercial practices. It has been maintained as an essentially agricultural country, whose exports are based on the commercialization of commodities devoid of added value (OECD 2018; Branco 2018). Furthermore, interrupted industrialization and constant international pressure for the payment of foreign debt have weakened the incentives for the country's industrial policy (Oreiro and Feijó 2010; Loures et al. 2006). In this context, economic stagnation has triggered the proliferation of political narratives that have tended to increase the rate of environmental devastation, which, in the Brazilian scenario, is being generated through the expansion of agribusiness, and other extractive industries.

This expansion has intensified forest burning, deforestation, environmental pollution and environmental disasters (INPE 2020b; Pontes 2020). Moving beyond environmental devastation, "corporate colonial systems" generate dynamics that also socially exclude local communities by undermining their cultures, languages and identities. This context illustrates the correlation between the deepening of economic exploitation and the community-related harm derived from state-corporate practices that are oriented towards escalating corporate power, economic development and capital accumulation at the expense of local communities, lands, natural resources and, in the Brazilian case, the labour of indigenous and African peoples.

Remarkably, the systematic reproduction of environmental victimization today in Brazil remains a direct legacy of the mechanisms of colonization. Despite minor transitions and changes in national policy, the gears of the colonial production system, characterized by the exploitation of slave labour (updated today by the use of modern forms of forced labour and labour in degrading conditions) and environmental destruction, still reflect the economic policy developed in Brazil (Bales 2016: 197-237). In this regard, legislative initiatives and regulatory policy aimed at protecting the environment are unlikely to succeed in a political and economic context that privileges environmental exploitation and ecological devastation as strategies of economic development (Lynch et al. 2013).

The environment has been a recurrent theme in critical criminology studies. It is possible to observe some advances in the field of "green criminology" (see e.g. White 2008; Brisman and South 2020; Hall et al. 2016), and in the field of green 
victimology (Hall 2014; Flynn and Hall 2017), which seek to expand the analysis of environmental victimization (and social and economic victimization deriving from it) beyond the traditional and selective notions of criminally labelled harmful activities, including from the perspective of animal (non-human) victimization (Flynn and Hall 2017).

In the Latin American context, there is the promising field of Southern green criminology (Goyes et al. 2017; Goyes and Nariño 2021; Böhm 2017, 2020). The latter subfield focuses on the relationship between European colonization from the 15th century, the destruction of the environment for commodity exploitation and the primitive accumulation of capital. The thesis of the current trend on Latin American environmental crimes is that these commercial practices have been intertwined, until today, with the economic development of Southern countries. The reproduction and deepening of corporate authoritarian dynamics are felt through the development of massive environmental and social harm (Goyes et al. 2017; Goyes and Nariño 2021; Prata 2020). The increasing damage generated by agroindustry and mining requires more systematic, empirical analysis which can provide specific insights into harmful corporate behaviour and the consequent forms of social, economic and environmental victimization. Environmental victimology, i.e. "the study of the social processes and institutional responses pertaining to victims of environmental crime" (White 2015: 33), provides a useful framework in this respect. Thus, a useful conceptual tool for capturing the deepening of the authoritarian dynamics that are reproduced in Amazon territories, as will be argued later, would be to reconcile the tenets of environmental victimology and the new research agenda regarding corporate victimology. This analytical framework would be responsible for assessing social and economic harm causation and the layers of corporate victimization throughout the range of different victims and stakeholders. This should be a first step towards providing corporate accountability for economic and environmental crimes and offences in the current scenario (Laufer 2017: 415; Saad-Diniz 2019a: 139-40).

Against this context, the essay is structured in the following way: 1) the first part, dedicated to the study of the convergences between corporate criminology and green criminology, will underline the main categories of environmental victimization and its central consequences for the development of social disintegration and social disorganization, promoting social damage on a large scale. In the second part, the Brazilian environmental regulatory rollback is addressed from the beginning of Jair Bolsonaro's presidential mandate, mainly from the analysis of the amendment and alteration of several laws and regulations aimed at protecting the environment and the main Brazilian biomes and indigenous communities' well-being. Third, a criminological analysis based on the consequences of deregulation (re-regulation) promoted by the Brazilian federal government is addressed. Finally, the last section is intended to discuss some attempts towards the development of gears of reversal by 
addressing corporate environmental and social victimization. The conclusions reveal the need for the development of corporate victimology as an analytical category responsible for addressing corporate harm and victimization practices.

\section{What does Green Criminology Say about Corporate Crime?}

In recent decades, corporate criminology has made some theoretical advances in criticizing the lack of accountability for corporate crimes. Some of the achievements could be summarized by the critique about the perpetuation of the selectivity of the criminal justice system, mainly in the Latin American context (Zaffaroni 2015: 13-26), and the obsession with punishment of street crimes (Saad-Diniz 2019a: 167-90). Corporate crime is rarely prosecuted, and when it is, scapegoating practices largely dominate the sentencing of individuals who occupy intermediate levels of corporate structures and are not the primary perpetrators of corporate crimes and offences (Goyes and Nariño 2021: 13).

Despite advances in criminology, various forms of harm and victimization in the business world lack answers that are minimally satisfactory for understanding the complexity of the problem (Laufer 2015; Garret 2014; Simpson 2019). Notably, the relationship between the capitalist system of production and the damages resulting from corporate deregulation (and regulatory rollbacks) (Wyatt et al. 2014) should focus on the reproduction of the authoritarian mechanisms developed by transnational corporations which are responsible for the deepening of violence though harmful activities caused by deregulation, which is particularly the case for Latin American countries and especially Brazil (Böhm 2019).

It is in this context that critical criminology has developed its critique of orthodox criminology, arguing that criminologists have neglected the study of a class of crimes that generate the most social damage and adverse results, also known as green crimes (van Sollinge 2014: 317). The development of green crimes results from the collusion between large corporations and the state, for the purpose of promoting sectoral economic development and political control.

Green criminology has conceptualized green crime as the product of joint participation between the state and the private sector, i.e. as a product of collusion between large corporations and government agencies, placing it among the crimes of the powerful and within the analytical category of state-corporate crime. The latter addresses the collusion between state and corporations for the commission of crimes against the environment. As an analytical tool, it provides room for green criminologists to explore the links between the state's deregulation of corporate activity and social, and environmental harm causation (Kramer 2014: 23-39).

The main motivation is explained by the irrepressible search for corporate profit and the growing quest to conquer new markets within the international 
globalized context. In this regard, corporate violence operates as a strategy characterized by the irrepressible search for the domination of new markets at the expense of the intensification of exploitation and degradation of the environment, including through practices of corporate greenwashing in the USA (Laufer, 2003: 253-61; Barak 2017: 4), as well as agribusiness greenwashing in Brazil (Goyes and Nariño 2021: 10; Budó 2017), which are responsible for the deepening of moral neutralization over corporate crime. Such problematic relationships between the deepening of corporate violence and environmental exploitation are responsible for causing large-scale victimization. Discussions on measurement techniques for assessing the damage still need to be addressed so that it is possible to develop possible reparations and victims' redress (Lynch 2020: 55).

\section{Regulatory Rollback and Environmental Victimization}

Before analysing the main reforms actioned by the Brazilian government, a small but close look at environmental governance in Brazil is needed. The legislative framework is enacted by the National Congress through the approval of both houses (the presidential sanction is not needed if the two houses agree on a final project). These Laws (of which the Brazilian Forestry Code is the most important) added with regulations enacted by the Brazilian Federal agencies, such as Ibama (Brazilian Institute of Environment and Renewable Natural Resources), ICMBio (Chico Mendes Institute for Biodiversity Conservation), and FUNAI (National Indian Foundation) are to be enforced by the Brazilian Courts as well as the federal agencies responsible for protecting the environmental and local indigenous communities. Furthermore, the President of the Republic, currently Jair Bolsonaro, can enact Executive Orders (power given by Constitutional prerogatives, Federal Constitution 1988) - recognized in Brazil as Provisional Measures (art. 62 of the Federal Constitution) or Federal Decrees (art. 84 of the Federal Constitution). The latter is designed to regulate and give further specificity to these laws and regulations. Whilst the Provisional Measure (Medida Provisória) has the same effect as a Law and can be enacted by the President in case of emergency, the Provisional Measure only has temporal validity until it is subject to the approval or rejection by Congress. In the latter case, the Provisional Measure loses its validity. During the interim period Provisional Measures can have significant impact. Within the time of their validity, these are capable of amplifying freedom of action by some actors, whose effects are then preserved and felt after the end of the Act's validity. Thus, by using these regulatory instruments the President can limit protections provided for the environment and indigenous communities, a subject that will be analysed in the next section to trace the main social, economic and ecological damage generated by Brazil's "regulatory rollback." 
Whilst the Brazilian health care system collapsed during the COVID-19 outbreak (see Urban and Saad-Diniz 2020), and death rates soared, the former Environment Minister, Ricardo Salles - a former lobbyist for the logging and agribusiness sector who is now being investigated for corruption and related criminal practices (Peron 2021) — called for further deregulation of environmental protection, as well as for decreasing investment and diminution of Ibama (the president of the institution is also under criminal investigations) and ICMBio. The former Brazilian Environment Minister suggested that the right-wing government should further the regulatory rollback, using the pandemic as cover, in order to "simplify regulation on a large scale" and "run the cattle herd" through the Amazon. His demands resonated with the government's interests, and although Salles had to leave office due to ongoing criminal investigations, his replacement has continued the same policy of environmental degradation (Spring and Marcello 2021).

As a consequence, a wide range of Executive Orders were enacted to roll back environmental regulations. These orders are responsible for inflicting harm on indigenous territories and the Amazon fauna and flora. Furthermore, the enactment of these Orders allowed private actors to grab land that was originally public and destined for the creation of conservation areas for indigenous peoples. Subsequently, these areas have been used for the perpetration of environmental crimes, such as illegal logging, mining and also for the deepening of violence against indigenous peoples that live nearby. Brazil's indigenous leaders have, thus, sued Jair Bolsonaro for crimes against humanity (Brum 2021). However, as substantive legal instruments in the international context are still lacking, the federal government's misconduct will likely persevere amid immense social, economic and environmental victimization. This leads Brazilian regulatory policies into a scenario characterized through the phrase "necropolitics of regulation," a scenario where the state has the power to decide who are to live and those who should die (Mbembe 2019; Michalowski 2020; Almeida 2019).

In Brazil, this project of destroying the main world biomes has been accompanied by a government strategy that benefits large companies, including through the cultivation of "regimes of permission" (Whyte 2014: 237-46). "Brazilian agribusiness" is aggressively supported by the government funding practices and regulatory laxity despite increasing negative impacts on nature, and the violent victimization of native populations. The harm generated by agribusiness practices has precipitated ecological and social breakdown. The deregulation of corporate activities promoted the decoupling of legislation and environmental regulatory policy in relation to law enforcement. Ultimately, the destruction of the policy responsible for protecting the national ecological heritage reflects the deepening of Brazil's democratic deficit. 
Alongside deregulation and state patronage, in a context marked by democratic deficit, permissive labour regimes are also critical to generating environmental and social harms. Data analysis produced by Brazil's main research institutions and NGOs demonstrates the interrelation between the advance of Amazon rainforest's deforestation and the use of modern slave labour, especially the exploitation of forced labour, the submission of the workers to debt bondage relationships and labour in degrading conditions for the enrichment of the Brazilian agribusiness and foreign investors (van Sollinge 2017: 272). These practices occur mainly on cattle ranches (Budó 2017: 187-8), in logging operations (Repórter Brasil 2021a, 2021b; Comissão Pastoral da Terra 2017) and wildcat mining, which lead to Amazon deforestation and pollution (see data from Ecocrime 2021). These dynamics are taking place in a broader environment marked by the indifference of public institutions and private companies to the social and moral costs arising from socially and environmentally harmful corporate behaviour (Jackson and Sparks 2020: 1-7; Sakamoto and Casara 2008; International Amnesty 2020; Rajão et al. 2020: 246-8).

To a large extent, the analysis of harms reveals a reproduction of colonial exploitation structures, characterized by the collusion between state and corporate interests under the pretence of economic development. The continuation of this dynamic helps to reproduce and bulwark the corporate sector's interest in regulatory rollback, or "capitalism re-regulation," which seeks to escalate corporate revenues. This process occurs through the intensification of old forms of production related to primitive accumulation, through the escalation of predatory capitalist practices (Michalowski and Brown 2019: 91-110; Lipton and Ivory 2019). The rollback of regulations responsible for protecting the environment, although powerful influences try to deny its harmful consequences, is related to the intensification of exploitation of people (labour), land and the biosphere. This intensifies environmental devastation and deepens victimization (Friederichs and Rothe 2020: 95-102).

The choice of the Brazilian regulatory rollback as an analytical standpoint to address the damage caused by green crimes has some important motivations. First, the regulatory rollback demonstrates in a practical way the intersection of interests between state and corporations in obtaining economic development at the expense of human beings and ecosystems. Second, the investigation of the Brazilian case for environmental deregulation provides an argument for the practical analysis of research frameworks previously developed. This holds true because private-sector pressures for the promotion of deregulation over corporate wrongdoing are caused by an activity initially carried out by the state itself, whose intentions are revealed by rapid economic growth (state-corporate crime) or by facilitation of corporate crime (state-facilitated corporate crime) (Michalowski and Brown 2020: 113-22), as the Brazilian regulatory rollback development is carried out in a similar way as 
the American deregulation process developed under Trump's presidency (for the latter, see Coglianese et al. 2020). In both cases the environment is an important sector for deregulation, ostensibly to solve economic issues and crisis (Coglianese and Walters 2019). Third, the analysis of this illegitimate relationship between government agencies and companies reflects the deepening of corporate power over human lives and the environment, in a context in which victimization is certain but accountability for crimes committed is exceedingly rare or non-existent. And fourth, the focus on regulatory rollback is an effective analytical perspective for understanding the enduring democratic deficit, and even its deepening in Brazilian society (Gonçalves et al. 2018: 348-95).

The election of the far-right Brazilian president, Jair Bolsonaro (in 2019), was accompanied by an intense project to legitimize environmental destruction, and starkly reveals the government's own complicity in environmental crimes (Rose-Ackerman and Pimenta 2020: 199; Vale et al. 2021: 1-5). Widely supported by Brazilian agribusiness in the 2018 presidential elections, Jair Bolsonaro began his environmental destruction project by promoting the regulatory rollback of environmental laws and regulations (Spring 2020). Bolsonaro has also initiated the process of disarticulation and internal destruction of the main state agencies responsible for monitoring, investigating and imposing administrative sanctions for environmental crimes (Conservation International 2021). Although some initiatives to promote deregulation preceded the Bolsonaro government (Hochstetler 2017), from the beginning his mandate focused on relaxing laws and changing regulatory policy, in order to remove the obstacles for the development of environmental and socially harmful corporate behaviour. This has occurred mainly through amendments to the Brazilian Forestry Code (Law 12.651/2012), which is responsible for enacting the Brazilian Environmental Policy towards sustainable development and economic equilibrium.

The loosening of laws and environmental regulations can, in the first instance, be witnessed with the adoption of the Provisional Measure no. 910/2019 (Brazil 2019b). The Executive Act is responsible for altering the Brazilian environmental legislation for the protection and regulation of environmental protection areas (Law 11.952/2019, 8.666/1993 and Law 6.015/1973). The content of this order is responsible for the regularization of the invasion of public lands (grilagem practices) by rural owners through the recognition of "legitimate possession" over these territories that originally belonged to the Brazilian state and to INCRA (National Institute of Colonization and Agrarian Reform). The measure extended the period established by the Brazilian Forestry Code (Art. 66, Law no. 12.651/1993), which allows the regularization of exploited lands until 22 July 2008, making it possible to recognize the ownership of squatted areas after this period. Furthermore, the presidential initiative regularizes practices of land grabbing or land squatting. 
Brazilian federal prosecutors published a technical report on the Federal Decree's consequences (content that is now under discussion for a bill awaiting a vote in the Brazilian parliament). According to the prosecutors, the regulation facilitates the land grabbing of state's federal reserves, the falsification of public documents to obtain undue recognition of ownership of invaded and occupied lands, and grants amnesty for perpetrators of environmental crimes (established by Law no. 9.605/1998) committed between 2011 and 2018 (Brazil 1966), ${ }^{1}$ including those related to illegal mining leading to pollution of the region (Ministério Público Federal 2020; Brito 2020). In addition, the regulation facilitates the intensification of pollution and deforestation in the Amazon rainforest, which has already reached the highest rate in the last ten years (devastation of 9,762 square kilometres in 2019). The new Provisional Measure (MP no. 910/2019) on land registration in Amazon rainforest territories will have potentially increased deforestation from 11 to 16 thousand $\mathrm{km}^{2}$ by 2027 , as the consulted researchers point out (Brito 2020).

The Executive Order's validity lasted for 120 days - according to Brazilian legislation (art. 62, CF/1988) (Brazil 1988). Following this period, the matter is now to be considered by bill no. 2633/2020, which is before Brazil's parliament (Brazil 2020b). This time, criticism has come from the international community after a letter from 41 representatives of international companies threatening to interrupt the purchase of Brazilian commodities if the bill was approved (Spring and Marcello 2020), so the vote on it has been postponed by the Brazilian Parliament. The same problematic dynamic has occurred with the adoption of Provisional Measure no. 884/2019 (Brazil 2019a) and its conversion in Law n. 13.887/2019 (Brazil 2019c). This law governs the regularization of illegal land grabbing and, therefore, favours the deforestation of the Brazilian biomes, and promotes violence against local indigenous peoples, in order to further certain economic practices (mainly soy and cattle ranching) in protected forest territories.

The combination of the different regulatory measures adopted to date has, as a totality, contributed to the increase of the deforestation arc, and the intensification of environmental exploitation in the Brazilian territory. As well, they have undermined the development of public policies that could help repair environmental damage, now that regulatory measures have, in effect, recognized the conquests of public lands (grilagem) - that should be conserved as public - as private properties for economic exploration (Junior et al. 2020: 1-6).

The current scenario thus shows the modest efforts that existed in Brazil to control environmental victimization have been rolled back. Furthermore, President Bolsonaro proposed bill no. 191/2020 (Brazil 2020a), whose content is intended to amend articles 176, $\S 1$, and 231, $\S 3$, of the Brazilian Constitution (exploitation of mineral wealth and water resources on indigenous lands recognized by the 
Brazilian state as Environmental Conservation Units, UCs). It also intends to make the rules regulating the exploitation of natural resources more flexible, in order to allow mining, and the extraction of oil and natural gas, without the affected indigenous peoples having power of veto over the occurrence of economic exploitation of the natural resources located in their territory (and are assured only the right to hearing). The bill, in addition to contradicting the constitutional provisions mentioned above, also contradicts article 6 of ILO (International Labour Organization) Convention no. 169, of which Brazil is a signatory, which seeks to ensure prior consultation with native communities regarding the economic activities to be developed in their territory (ILO 1989).

There are convincing, evidence-based arguments that recent attempts to loosen the protection afforded to indigenous population and natural resources located in the Amazonian territory are designed to further the exploitation of the territory by large multinational mining companies (Angelo 2020). As an example, the multinational mining company AngloAmerican, and its two Brazilian subsidiaries, are seeking to exploit natural resources in indigenous lands. Until now, the company has submitted 300 applications to dig for gold and other minerals. The bill also contradicts national evidence of environmental devastation by the exploitation of the Amazon rainforest's natural resources. Data analysis produced by the National Institute of Space Research (INPE) has demonstrated the worsening deforestation and environmental devastation from 2019, at rates above $29 \%$, with the total amount of deforestation in the Amazon reaching more than 10,000 square kilometres (INPE 2020a). In Brazil as a whole, the deforestation rates reached 12,000 square kilometres (INPE 2019; Mapbiomas 2020; INPE/Terrabrasilis 2021). ${ }^{2}$

Brazilian government agencies have exhibited serious deficiencies when overseeing illegal logging and deforestation in the Amazon rainforest territories. Law enforcement in the Amazon territories is poorly developed, which provides space for more environmental exploitation and the victimization of native peoples (van Sollinge 2017: 269-73). The tendency towards the promotion of environmental regulatory rollback at the federal level can also be analysed at the state level. Maranhão state in Brazil has been suffering as a result of deregulation since its governor reduced the protected area from $80 \%$ to $50 \%$ in a public policy initiative known as "Zoneamento Ecológico Econômico MaranhenseBioma Amazônico". The Brazilian deforestation reports show an increase in environmental destruction within government-protected areas. In 2019, 10,129 square kilometres were devastated from the Legal Amazon Region (Amazônia Legal Brasileira) that covers nine Brazilian states (Acre, Amazonas, Amapá, Maranhão, MatoGrosso, Pará, Rondônia, Roraima and Tocantins) (INPE 2020a). In 2020 the same tendency towards deforestation enlargement continued (Escobar 2020) as can be seen in Figure 1. 


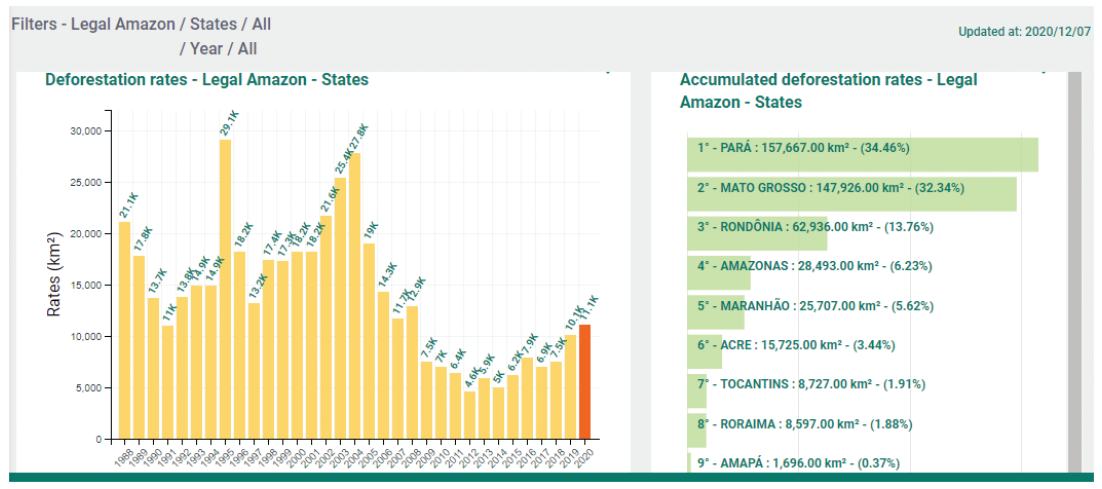

Fig. 1.

Source: INPE/Terrabrasilis 2021 (available at: http://terrabrasilis.dpi.inpe.br/app/dashboard/deforestation/biomes/ legal_amazon/rates).

The regulatory rollback can also be analysed by taking a closer look at the shrinking of national agencies responsible for the development of formal social control, monitoring and inspection of environment and natural resources. Since the beginning of the Bolsonaro presidential mandate, the national environmental protection agencies-IBAMA, ICMBio, and FUNAI — have suffered from cuts in funding and a drastic reduction in the number of employees. Government initiatives have also diminished informal social controls of environmental crimes through the reduction of civil society participation in CONAMA (National Environmental Council) discussions and through the extinguishing of its participation in the National Environmental Fund (FNMA) (Bragança 2020). The initiatives responsible for promoting environmental reconstruction and repairing the damage caused by environmental crimes were also squandered by the federal government through the extinction of the Amazon Fund, which concentrated donations from foreign countries - mainly Germany and Norway-aimed at promoting public policies for the preservation of the Amazon rainforest (Rodrigues 2019).

A criminological analysis of Brazilian government initiatives demonstrates a scenario tending to favour the failure of both environmental protection and of the reparation of damage generated by harmful corporate behaviour. In the first place, regarding formal social control, the shrinking of public agencies responsible for monitoring and investigating environmental crimes has caused a decoupling between legislation, regulation and the development of strategies for the detection of environmental crimes. The dismantling of enforcement agencies has significantly decreased the likelihood of crime detection or punishment, essential 
elements of any crime prevention strategy (Braithwaite 2018: 69-118; Armour et al. 2020: 5).

Likewise, the disarticulation of informal social control strategies is responsible for undermining accountability for corporate crimes - and thus their punishment. It is also responsible for deepening the democratic deficit in the construction of regulatory policy for environmental protection (Braithwaite 2006). Thus, the strategies of the federal government clearly point to the escalation of illegitimate interactions with the private sector, increasing the practice of state-corporate crime and diminishing law enforcement authorities responsible for the investigation and punishment of environmental offences. To a larger extent, the result promises to support impunity for environmental crime, and escalate environmental and social victimization.

\section{Harm and Victimization in Brazil}

First, environmental victimization through green crimes faces significant resistance to its recognition not only by offenders, but by the state itself-including the criminal justice system - and by society in general. This occurs because, generally, green victimization is promoted by the development of the harmful activity of large corporations and industries and, therefore, is usually neutralized, naturalized or routinized away through the development of moral justifications regarding national or corporate economic development. Specifically, the deepening of environmental victimization for the increase of private companies' profits is justified through the creation of jobs and a false narrative around socio-economic development (Barak 2017: 42-65; Burchard 2010; Vetlesen 2005: 84-9). In this context, despite the immense social and environmental costs of socially harmful corporate behaviour, the harm caused is often not even considered as a crime. This fact demonstrates the difficulty in promoting accountability towards green crimes, as well as their punishment (White 2008: 85-6).

Green criminology has been trying to demonstrate that the old patterns associated with environmental crimes are no longer sufficient to describe and analyse the processes of victimization in the ecological sphere, and that ecological justice must begin with the recognition of new criminal actions beyond the traditional criminal offences incorporated by national legislation. In this context, Rob White has categorized green crimes into two main groups: primary crimes (the destruction and degradation of the earth's resources through human actions) and secondary or symbiotic crimes (resulting directly from the destruction and degradation of the earth's resources, through human actions). The first group is composed of crimes of air pollution, deforestation, crimes of species decline and against animal rights, and crimes of water pollution. The second group is composed of state 
violence against oppositional groups, hazardous waste and organized crime (e.g. toxic and general waste dumping, both legal and illegal) (White 2008).

Initiatives developed within the green criminology field seek to counter these two main groups of green crime. The first initiative is described as the "rhetorical dimension," oriented toward stigmatization of certain acts and omissions, and the second refers to the "aspirational element," aimed at criminalizing those acts and omissions responsible for large-scale ecological victimization. Therefore, the analytical category of ecocide was created to criminalize the conduct responsible for the destruction and diminishing of "the wellbeing and health of ecosystems and the species within them (including humans), for which there are varying degrees of responsibility" (White 2018; Martín et al. 2019). Ecocide has, as its major characteristic, the massive destruction of environment, which occurs at a large scale, through the "destruction, degradation and demolishment of ecosystems and specific environments, with harmful consequences for the living creatures to which they are home" (White 2018).

The forms of corporate victimization promoted by green crimes cause different damage according to the countries where they operate and, within these, victimizes differently according to socio-economic sectors, social classes, as well as according to gender and ethnic intersections. In the first place, the globalized context allows the economic activities developed within business supply chains to be distributed to different parts of the globe. Within this framework, national contexts characterized by regulatory capture and practices of business lobbying, as well as monitoring and enforcement loopholes by state authorities, can be and are used in favour of companies, which distribute their production according to the lowest production costs, at the expense of human rights violations in countries most vulnerable to corporate violence (White 2010b: 3-18).

Moreover, within the countries themselves, victimization also occurs differently and is distributed according to contexts of vulnerability. According to Matthew Hall, green victimization tends to harness and deepen the dynamics of inclusion and exclusion in the social context in which it occurs. This means that social minorities, socio-economically marginalized classes and inequalities of ethnicity and gender present contexts for deepening victimization (Hall 2014; White 2010). In the Brazilian context, the impact of agribusiness practices through Amazon territories especially victimizes indigenous peoples through increasing social and ecological harms. They are responsible for structural violence, destroying indigenous habitats, killing indigenous peoples and environmental activists, and their own cultural and oral history (De Caravalho et al.2021: 258-64).

To a larger extent, green criminology developed within the Southern context seeks to demonstrate that the colonial dynamic of corporate power concentration and its relationship with the state justice system and regulatory policy endure today. 
Updated analysis shows that the tendency towards deregulation promotes economic development at the expense of social and environmental damage, in a context marked by the absence of criminalization of harmful corporate wrongdoings, although they represent a major social and ecological threat. Beyond the criminalization process, the environmental exploitation and the harm derived from corporate violence reproduces the lack of accountability toward corporate socially harmful behaviour, reflecting the same tendencies upheld by corporate colonial systems of exploitation, in which the collusion between corporate and state's interests result in the development of segregation and marginalization of local communities, which escalates from social and economic inequality, as well as state and corporate violence towards native peoples (De Carvalho et al. 2021: 258-64).

Despite the harmful impact, it may be hypothesized that at least this hyperexploitative activity delivers on its economic mandate. However, it is largely known that, despite environmental destruction and native peoples' victimization, especially in the Amazon, agribusiness's exploitation and degradation practices developed in the Amazon territories are also linked to practices of tax avoidance which undermine its use for the development of public services for the fulfilment of public interest (Folloni and Borghi 2019). This means that the practices we have outlined are sustained for the benefit of criminal actors, and do not deliver any major economic profit for the country. Meanwhile, the biodynamic induced by human economic exploitation of Amazon's natural resources lead to its fauna and flora being put in great danger of extinction (Patriani 2021), pollution of the Amazon basin, higher carbon emissions and consequently the acceleration of climate change and global warming (Silverio et al. 2013).

Not only is the environment victimized in this spiral of damage causation. The local indigenous populations suffer great harms from these corporate practices, and, in a broader sense, from the capitalist treadmill of production. Beyond this, the creation of regimes of permission (Whyte 2014) by the state, through more lenient laws and regulations is responsible for the increase of violence against indigenous peoples by the local agribusiness practitioners, mainly for the production of soy, cattle ranching, illegal logging and illegal mining. The latter is responsible for poisoning lands and water used for the subsistence of the Yanomami indigenous tribe, which is leading to the increase in deaths by native peoples in the state of Roraima where approximately 5,000 illegal miners are currently operating on native peoples' lands. In some villages where the Yanomami peoples live, over $90 \%$ of the local population tested showed high levels of mercury poisoning (Ecocrime 2021).

Furthermore, communities are being impacted by land grabbing in the Amazon territories - which is exacerbated by the environmental regulatory rollbackundertaken by local ranchers (large landowners) that have significant power at 
local levels. These farmers are considered as even stronger than the Brazilian National Forces (Zinet et al. 2012), and seek to capture indigenous reserves in order to provide space for more environmental exploitation (Gentili and Stuckert 2019). Contemporary data from the Ecocrime platform show that "297 titled indigenous lands have part of their territory registered by private landholders in the Rural Environmental Registry (CAR)" (Ecocrime 2021). These data reveal that 7,000 private properties are registered (illegally) in indigenous lands. Conflicts over land conquest in the Amazon legal area have resulted in the massacre of the Brazilian indigenous tribe called Guarani-Kaiowá in the state of Mato Grosso do Sul (CDHM 2020: 70-2).

The local community includes environmental activists who are also victimized when reporting environmental and social victimization in the Amazon territories. This occurred with the rubber tapper and an important environmental activist Chico Mendes (killed by the son of a rancher), and his sister Dorothy (killed in the state of Pará while leading important conservation work and social projects for the poor people of the region), two of the most important environmental activists from the Amazon territory (van Sollinge 2010: 268-73). In 2020, Brazil was recognized as the most lethal country for environmental activists. Global Witness (2020) records the highest number of land and environmental activists murdered in one year in the Amazon territory, and this is responsible for opening new paths to environmental destruction.

\section{From Ecological Hazard to Ecological Disorganization}

Green criminality is systemic. This means that ecological damage is part of a structural problem, caused by the development of the capitalist system, its production forces and its productive structure. In this approach, the development of capitalism through the intensification of environmental exploitation acts as a criminogenic context, favourable to the intensification of green crime commission and reproduction of ecological harm (Lynch et al. 2015: 117; Barak 2017: 91). Furthermore, green crimes produce and reproduce structural damage that accelerates and intensifies environmental destruction. They produce ecological disorganization and, consequently, the development of social disorganization, as they undermine social control strategies and law enforcement of corporate harmful wrongdoing (Lynch et al. 2013).

As critical criminology analyses note, despite the significant victimization visited upon nature, non-human animals and communities, environmentally violent corporate practices are usually disregarded as costs necessary to promote economic development, whose benefits are restricted to powerful sectors of the society (Ruggiero and South 2010: 245-50; Brisman and South 2020: 39-45; Lynch et al. 2013) 
The abuse in the exercise of corporate power and the violence inflicted by companies through the intensification of environmental exploitation in pursuit of increased profit and competitiveness are causing ecological disorganization. This occurs when there is the addition of pollution to ecosystems (pollutants that the treadmill of production adds to the environment), known as ecological additions, or when resources are taken from nature to be used by the corporate and industrial productive chains, a practice known as ecological withdrawals (derived from deforestation and mining practices, for example). At a global level, these green crimes are responsible for the development of deep metabolic changes in nature, known as ecological disorganization, which manifests itself in the intensification of global warming, destruction of tropical forests, extinction of animal and plant species, alteration of water systems, among other numerous effects (Agnew 2011: 35).

This conceptualization is relevant in reflecting on the consequences of green crimes for society, as well as in addressing the need for reflection on the systemic character of the damage caused by green crimes. Its main characteristics encompass large-scale victimization, which is distributed in space and time, responsible for transforming spaces occupied by human communities into uninhabitable places, the degrading and destruction of ecosystems, as well as externalization of business costs at the expense of human health and lives, along with non-human victimization (Flynn and Hall 2017).

Regarding techniques for measuring damage, the ways of assessing the harm caused by green crimes differ substantially from the same activity associated with traditional crimes (street crimes). Measuring damage involves analysis, as well as the evaluation of different localities where the damage is perpetrated and extended. The damage caused by environmental economic crimes extends not only to the localities where its consequences are observed, but also to other regions where the consequences develop harmful impacts over time. There are also those crimes whose consequences cannot be measured quantitatively, being only observable through qualitative analysis of the damage. This fact contributes to difficulties in the elaboration of restoration and repairing strategies, as in the case of climate change, planetary environmental boundaries, ecological footprint and the extinction of species, which could not be repaired due to the nature of the harm perpetrated (Lynch 2020: 55-7).

Despite minor financial benefits for those involved, the practices developed by Brazilian agribusiness are also intertwined with ecological disorganization in the Amazon territory, responsible for the development of the bioprocess called "savannization". This process is transforming the Amazon's ecological heritage, containing almost $30 \%$ of the biodiversity of the world, into a savanna. The deepening of this process is disrupting the survival of tropical rainforests (Vasconcelos and Conceição 2021; Sales et al. 2020) caused by the increase of deforestation rates, forest burning and native species extinction. These biological processes induced 
by corporate harmful activities in the Amazon are also increasing the presence of carbon in the atmosphere, which is responsible for the acceleration of global warming and climate change. Consequently, the harmful activities derived from the exploration of the most important biome of the globe are responsible for diffuse, large-scale victimization, which is not restricted to the Amazon indigenous peoples, but affects the whole world through the increase in global temperatures, alteration of the biosphere, extinction of species necessary for ecological equilibrium, water pollution, destruction of the ozone layer. All of these are significantly caused by the replacement of the tropical forests by degraded grass (pasture), leading to a great increase in surface temperature and a decrease in evapotranspiration and precipitation over Amazonia (Shukla et al. 1990).

\section{Concluding Remarks}

To properly reckon with environmental victimization demands new social practices guided by scientific research in the criminological sciences. One of the most promising research strategies is in the field of corporate victimology. Originally developed by Laufer, this field is dedicated to the study of the relationships between corporate fault, harm and victimization processes (Laufer 2017; Saad-Diniz 2020: 139-40). Another promising approach resides within the green victimology framework, which is concerned with assessing corporate environmental harmful practices and their impact upon the environment (fauna and flora), as well as human victimization, mainly from the perspective of social minorities (Flynn and Hall 2020; Hall 2017). Southern green criminology seeks to analyse the reproduction of the colonial systems of exploitation nowadays, including by analysing the role played by corporations in deepening ecological harm and victimizing indigenous peoples (Goyes and Nariño 2021). All of them seek to advance the debate on harm causation beyond the crime label to new empirical analyses regarding corporate behaviour, harm causation and the processes of victimization deriving from it. It is from this analytical standpoint that the interconnected relationship between corporate violent practices and social, economic and ecological victimization should be addressed.

There is much to be investigated regarding the processes of corporate victimization. The victim's exclusion from the process reflects the obstacles to improving the effective information, participation and inclusion regime. Analysing corporate victimization processes can offer significant insights, especially by determining how victimization causes disorder and disrupts social cohesion in victimized communities. In the empirical verification of social damage, the most important thing of all is to demonstrate how business activity impacts social interactions, weakening social links and dismantling community relations as well as sustainable practices (Adams and Serpe 2000). 
This is the empirical basis from which strategic recommendations can be extracted, and it can guide the allocation of resources to reduce the impact of victimization processes. Despite this, no matter how sophisticated or theoretically consistent it appears to be, its repercussion in the criminal justice system is still far from practical implementation. Meanwhile, the mechanisms of environmental victimization, rather than being reversed, are deepening their deleterious impact globally, and especially in Brazilian society.

A turning point in the current Brazilian scenario, marked by the devastation of the Amazon and victimization of local populations, would be to promote a regulatory turn concerning public environmental policies. This is already happening in the USA, where President Biden is developing a new agenda focused on "Modernizing Regulatory Review" (The White House 2021; Sunstein 2021) directed at reversing Donald Trump's regulatory rollback agenda, doing a cost-benefit analysis in favour of more regulation of economic activity. In Brazil, although federal government's election is yet to happen, rigorous empirical research on corporate victimization practices, capable of enhancing evidence-based policy strategies, could also address a turning point to improve regulation over the Amazon's exploitation, and thus enhance public interest (for the perspective of regulations for public interest achievement, see Coglianese 2012). Using data registering the escalation of environmental damage in precise locations, including information on its perpetrators and victims, could inform public policies regarding the protection of the Amazon rainforest's territories. This could be a milestone responsible for improving protection and monitoring environmental offences. Although this might seem distant from reality, a technology-driven perspective towards monitoring and detecting deforestation and forest burning in the Amazon is currently in place and needs to be improved for further use by the Brazilian enforcement agencies. The system consists of data provided by the PRODES (a geographical information system) and used by DETER (real-time deforestation detection), which analyses the data provided and sends important information about the probable statute and regulatory violations to law enforcement agencies for investigation (Mujtaba and Karam 2017). The mapping and monitoring of environmental deforestation could also be used for social purposes through the monitoring of social victimization and local communities' human rights violations.

Also, by fostering the tenets of shared responsibility between Western societies and Latin-American countries (in this case, Brazil) to the Amazon, an international initiative could also focus on smart solutions provided by technological advances, which focus on data provided by satellite images over time for the development of machine learning techniques (for the shared responsibility perspective, see van Sollinge 2017: 275-6). These could provide some predictors for deforestation rates, also noting areas more vulnerable to environmental and social 
victimization. Particularly in Brazil, this movement could be initially developed by utilizing advances in deforestation data to map the next probable areas likely to be impacted by deforestation practices. This could be the starting point for reversal mechanisms that address social and environmental victimization in the Amazon, and for developing a more promising approach to state-corporate crime prevention in one of the most biodiversity-rich biomes in the world.

\section{Notes}

1. Art. 20, Law no. 4.947/1966: Invade with intention to occupy the state's public lands. Sanction: Detention-from six months to three years.

2. Brazilian deforestation is well documented by many satellites coordinated by the DETER program developed under INPE's inspection. For details, see: http://terrabrasilis.dpi.inpe.br/app/dashboard/ deforestation/biomes/amazon/increments.

\section{References}

Adams, R. and Serpe, R. (2000) "Social Integration, Fear of Crime, and Life Satisfaction”, Sociological Perspectives, Vol. 43: 605-29.

Agnew, R. (2011) "Dire Forecast: A Theoretical Model of the Impact of Climate Change on Crime", Theoretical Criminology, 16(1): 21-42.

Alencastro, L.F. (2000) Trato dos viventes: formação do Brasil no Atlântico Sul. Séculos XVI e XVII. São Paulo: Companhia das Letras.

Almeida, S. (2019) Racismo estrutural. São Paulo: Pólen Produção Editorial LTDA.

Angelo, M. (2020) "Anglo American Seeking to Mine on Indigenous Lands in Brazil's Amazon", Mongabay. Available online at: https://news.mongabay.com/2020/03/anglo-american-seeking-tomine-on-indigenous-lands-in-brazils-amazon/ (accessed 24 August 2020).

Armour, J., Gordon, J. and Min, G. (2020) “Taking Compliance Seriously”, Yale Journal on Regulation, 37(1): $1-66$.

Bales, K. (2016) Blood and Earth: Modern Slavery, Ecocide, and the Secret to Saving the World. New York: Spiegel \& Grau.

Barak, G. (2017) Unchecked Corporate Power: Why the Crimes of Multinational Corporations are Routinized Away and What we can Do about it. New York: Routledge.

Böhm, M.L. (2017) "Empresas transnacionales, violaciones de derechos humanos y violencia estructural en América Latina: un enfoque criminológico", Crítica Penal y Poder, Vol. 13: 41-65.

Böhm, M.L. (2019) The Crime of Maldevelopment: Economic Deregulation and Violence in the Global South. New York: Routledge.

Böhm, M.L. (2020) Empresas transnacionales, recursos naturales y conflicto en América Latina: Para una visibilización de la violencia invisible. Buenos Aires: Universidad de Buenos Aires.

Bragança, D. (2020) "Bolsonaro retira sociedade civil do Fundo Nacional do Meio Ambiente", OECO. Available online at: https://www.oeco.org.br/noticias/bolsonaro-retira-sociedade-civil-do-fundonacional-do-meio-ambiente/ (accessed 24 August 2020).

Braithwaite, J (2006). "Responsive Regulation and Developing Economies", World Development, Vol. 34: 884-98.

Braithwaite, J. (2018) "Minimally Sufficient Deterrence”, Crime and Justice, Vol. 47: 69-118. 
Braithwaite, J. (2020) "Regulatory Mix", Journal of White Collar and Corporate Crime, 1(1): 62-71. Braithwaite, J. and Fisse, B. (1993) Corporations, Crime and Accountability. New York: Cambridge University Press.

Branco, M. (2020) "Brazil Tackles Challenge of Selling More Value-Added Goods: Most Exports Today are Non-Manufactured Products", Agência Brasil, 26 September 2018. Available online at: https://agenciabrasil.ebc.com.br/en/economia/noticia/2018-09/brazil-tackles-challenge-sellingmore-value-added-goods (accessed 17 August 2020).

Brazil (1966) Law no. 4.947, Apr. 6, 1966. Available online at: http://www.planalto.gov.br/ccivil_03/ leis/14947.htm (accessed 01 February 2021).

Brazil (1988) Federal Constitution 1988. Available online at: http://www.planalto.gov.br/ccivil_03/ constituicao/constituicao.htm (accessed 23 August 2020).

Brazil (2012) Law no. 12.651, May. 25, 2012. Available online at: http://www.planalto.gov.br/ ccivil_03/_ato2011-2014/2012/lei/112651.htm (accessed 24 August 2020).

Brazil (2019a) Executive Orders no. 884/2019. Available online at: http://www.planalto.gov.br/ ccivil_03/_ato2019-2022/2019/Mpv/mpv884.htm (accessed 01 February 2021).

Brazil (2019b) Executive Order no. 910/2019. Available online at: http://www.planalto.gov.br/ ccivil_03/_ato2019-2022/2019/Mpv/mpv910.htm (accessed 22 August 2020).

Brazil (2019c) Law 13.887/2019. Available online at: http://www.planalto.gov.br/ccivil_03/_Ato20192022/2019/Lei/L13887.htm (accessed 01 February 2021).

Brazil (2020a) Bill no. 191/2020. Available online at: https://www.camara.leg.br/proposicoesWeb/ prop_mostrarintegra;jsessionid=2CFBC941454316B9CA0F517B00CCD7D8.proposicoesWebEx terno1? codteor $=1855498 \&$ filename $=P L+191 / 2020$ (accessed 01 February 2020).

Brazil (2020b) Bill no. 2633, 2020. Available online at: https://www.camara.leg.br/proposicoesWeb/ prop_mostrarintegra?codteor=1893531 (accessed 22 August 2020).

Brisman, A. and South, N. (2020) "The Growth of a Field: A Short History of a 'Green' Criminology", in A. Brisman and N. South, eds., Routledge International Handbook of Green Criminology. New York: Routledge.

Brito, B. (2020) "Nota Técnica sobre o segundo relatório do Senador Irajá Abreu referente à Medida Provisória (MP) n. ${ }^{o}$ 910/2019”, Imazon. Available online at: https://k6f2r3a6.stackpathcdn.com/wpcontent/uploads/2020/02/Nota_Tecnica_MP910_2019_FINAL.pdf (accessed 01 February 2021).

Brum, E. (2021) "Study Finds that Brazil's Jair Bolsonaro Carried out an 'Institutional Strategy to Spread the Coronavirus'", El Pais, 29 January. Available online at: https://english.elpais.com/ americas/2021-01-29/study-finds-that-brazils-jair-bolsonaro-carried-out-an-institutional-strategyto-spread-the-coronavirus.html (accessed 01 February 2021).

Budó, M.N. (2017) “As mortes no campo e a operação greenwashing do 'agro': invisibilização de danos sociais massivos no Brasil”, Revista InSURgência, 3(3): 163-207.

Burchard, C. (2010) "Ancillary and Neutral Business Contributions to 'Corporate-Political Core Crime", Journal of International Criminal Justice, Vol. 8: 919-46.

Camargo, S. (2020) "As táticas do governo brasileiro para sucatear órgãos de proteção ambiental", Mongabay. Available online at: https://brasil.mongabay.com/2020/06/as-taticas-do-governo-brasileiro-para-sucatear-orgaos-de-protecao-ambiental/ (accessed 24 August 2020).

Centro de Defesa da Vida e dos Direitos Humano Carmen Bascarán; Comissão Pastoral da Terra (2016). Por debaixo da floresta. Amazônia paraense saqueada com trabalho escravo. Tocantins: CPT.

Clinard, M. and Yeager, P. (2011) Corporate Crime. New York: Transaction Publishers.

Coglianese, C. (2012) "Measuring Regulatory Performance: Evaluating the Impact of Regulation and Regulatory Policy", OECD Expert Paper, Vol. 1: 3-59. 
Coglianese, C. and Walters, D.E. (2019) "Whither the Regulatory 'War on Coal' Scapegoats, Saviors, and Stock Market Reactions”, Faculty Scholarship at Penn Law, 19(3): 1-55.

Coglianese, C., Sarin, N. and Shapiro, S. (2020) "Deregulatory Deceptions: Reviewing the Trump Administration's Claims about Regulatory Reform. Penn Program on Regulation.” Available online at: https://www.theregreview.org/2020/11/02/coglianese-sarin-shapiro-deregulatory-deceiving/ (accessed 22 October 2021).

Comack, E. (2018) "Corporate Colonialism and the 'Crimes of the Powerful' Committed Against Indigenous Peoples of Canada”, Critical Criminology, Vol. 26: 455-71.

Comissão de Direitos Humanos e Minorias, Câmara dos Deputados (2020) "Relatório Atividades 2020 [Report of Activities, 2020]", Congresso Nacional. Available online at: https://www2.camara.leg. br/atividade-legislativa/comissoes/comissoes-permanentes/cdhm/relatorios-de-atividades/relatorios-anuais (accessed 1 February 2021).

Conservation International (2021) "Global Conservation Rollbacks Tracker". Available online at: https:// www.conservation.org/projects/global-conservation-rollbacks-tracker (accessed 20 August 2021).

de Carvalho, S., Goyes, D.R. and Vegh Weis, V. (2021) "Politics and Indigenous Victimization: The Case of Brazil”, British Journal of Criminology, 61(1): 251-71.

Ecocrime Data (2021) "Mapping Environmental Crime in the Amazon". Available online at: https:// ecocrime.igarape.org.br/ (accessed 14 June 2021).

Escobar, H. (2020) "Dados de monitoramento por satélite apontam para nova escalada de fogo e ocupações na Amazônia e outros biomas", University of São Paulo (USP) Journal. Available online at: https://jornal. usp.br/ciencias/pesquisadores-temem-explosao-de-desmatamento-em-2020/ (accessed 14 June 2021).

Flynn, M. and Hall, M. (2017) "The Case for a Victimology of Nonhuman Animal Harms", Contemporary Justice Review, 20(3): 299-318.

Folloni, A. and Borghi V. (2019) "Tributação do agronegócio (ITR, ICMS e FUNRURAL) e desenvolvimento sustentável", Revista Eletrônica do Curso de Direito da UFSM, 14(2): 1-24.

Friederichs, D.O. and Rothe, D.L. (2020) "Regulatory Rollback and White-Collar Crime in the Era of Trump: The Challenges of Perspective", Journal of White-Collar and Corporate Crime, 1(2): 95-102.

Garret, B.L. (2014) Too Big to Jail: How Prosecutors Compromise with Corporations. Cambridge, MA: Harvard University Press.

Gentili, P. and Stuckert, R. (2019) Amazonas:vidas en peligro: pueblos indigenas de Brasil. Rio de Janeiro: Faculdade Latino-americana de Ciências Sociais.

Global Witness (2020) "Global Witness Records the Highest Number of Land and Environmental Activists Murdered in One Year-with the Link to Accelerating Climate Change of Increasing Concern", 29 July. Available online at: https://www.globalwitness.org/en/press-releases/globalwitness-records-the-highest-number-of-land-and-environmental-activists-murdered-in-one-yearwith-the-link-to-accelerating-climate-change-of-increasing-concern/ (accessed 23 April 2020).

Gonçalves, R.J.A.F.G., Milanez, B. and Wanderley, L.W. (2018) "Neoextrativismo Liberal-Conservador: a Política Mineral e a Questão Agrária no Governo Temer", OKARA Geografia em Debate, 12(2): 348-95.

Goyes, D.R. and Nariño, A. (2021) "Environmental Crime in Latin America and Southern Green Criminology”, Criminology and Criminal Justice, 1-22.

Goyes, D.R., Mol, H., Brisman, A. and South, N. (2017) Environmental Crime in Latin America: The Theft of Nature and the Poisoning of the Land. London: Springer.

Hall, M. (2014) "Environmental Harm and Environmental Victims: Scoping out a 'Green Victimology", International Review of Victimology, 20(1): 129-43.

Hall, M., Nurse, A., Potter, G.R. and Wyatt, T. (2016) "The Geography of Environmental Crime”, in G. Potter, A. Nurse and M. Hall, eds., The Geography of Environmental Crime. Palgrave Studies in Green Criminology. London: Palgrave Macmillan. 
Hellman, J. (2014) “The Fifth Crime under International Criminal Law: Ecocide?”, in D. Brodowski, K. Tiedemann, M. Parra, and J. Vogel, eds., Regulating Corporate Criminal Liability. Heidelberg: Springer.

Higgins, P., Short, S. and South, N. (2013) "Protecting the Planet: A Proposal for a Law of Ecocide", Crime Law and Social Change, Vol. 59: 251-66.

Hillyard, P. and Tombs, S. (2004) "Beyond Criminology?", in P. Hillyard, C. Pantazis, S. Tombs and D. Gordon, eds., Beyond Criminology: Taking Harm Seriously. London: Fernwood Publishing.

Hochstetler, K. (2017) “Tracking Presidents and Policies: Environmental Politics from Lula to Dilma”, Policy Studies, 38(3): 262-76.

INPE (2019) “A estimativa da taxa de desmatamento por corte raso para a Amazônia Legal em 2019 é de $9.762 \mathrm{~km}$ ". Available online at: http://www.inpe.br/noticias/noticia.php?Cod_Noticia=5294 (accessed 18 August 2020).

INPE (2020a) A taxa consolidada de desmatamento por corte raso para os nove estados da Amazônia Legal (AC, AM, AP, MA, MT, PA, RO, RR e TO) em 2019 é de $10.129 \mathrm{~km} 2$. Available online at: http://www.inpe.br/noticias/noticia.php?Cod_Noticia=5465 (accessed 20 September 2021).

INPE (2020b) "Cerrado, Amazon Rainforest and Pantanal are the Most Damaged Biomes". Available online at: http://queimadas.dgi.inpe.br/queimadas/portal-static/situacao-atual/ (accessed 20 August 2020).

INPE/Terrabrasilis (2021) “Deforestation Rates. Legal Amazon”. Available online at: http://terrabrasilis. dpi.inpe.br/app/dashboard/deforestation/biomes/legal_amazon/rates (accessed 20 August 2021).

International Amnesty (2020) "Da floresta à fazenda gado bovino criado ilegalmente na Amazônia brasileira encontrado na cadeia de fornecimento da JBS". Available online at: https://anistia.org.br/wpcontent/uploads/2020/07/da-floresta-a-fazenda-pt-amr-1926572020.pdf (accessed 24 August 2020).

International Labour Organization (1989) Convention no. 169/1989. Available online at: https://www. ilo.org/dyn/normlex/en/f?p=NORMLEXPUB:12100:0::NO::P12100_INSTRUMENT_ID:312314 (accessed 1 February 2021).

Jackson, B. and Parker Sparks, J.L.P. (2020) "Ending Slavery by Decarbonisation? Exploring the Nexus of Modern Slavery, Deforestation, and Climate Change Action via REDD+", Energy Research and Social Science, Vol. 69: 1-7.

Junior, C.H.L.S., Celentano, D., Rousseau, G.X., Moura, E.G., Varga, I.D., Martinez, C. and Martins, M.B. (2020) "Amazon Forest on the Edge of Collapse in the Maranhão State, Brazil", Land Use Policy, Vol. 97: 1-6.

Kramer, R. (2014) “Climate Change: A State-Corporate Crime Perspective”, in T. Spapens, R. White and M. Kluin, eds., Environmental Crime and its Victims: Perspectives within Green Criminology. Burlington, VT: Ashgate.

Laufer, W.S. (2003) "Social Accountability and Corporate Greenwashing”, Journal of Business Ethics, 43(3): 253-61.

Laufer, W.S. (2008) Corporate Bodies and Guilty Minds: The Failure of Corporate Criminal Liability. Chicago: University of Chicago Press.

Laufer, W.S. (2015) "The Compliance Game”, in E. Saad-Diniz, D. Brodowski and A.L. Sá, eds., Regulação do abuso no âmbito corporativo: o papel do direito penal na crise financeira. São Paulo: LiberArs.

Laufer, W.S. (2017) “The Missing Account of Progressive Corporate Criminal Law", New York University Journal of Law and Business, Vol. 14: 1-63.

Lipton, E. and Ivory, D. (2019) “Trump Says his Regulatory Rollback Already is the 'Most Far-Reaching”, New York Times, 14 December. Available online at: https://www.nytimes.com/2017/12/14/us/politics/ trump-federal-regulations.html (accessed 8 September 2020). 
Loures, R.C.R., Oreiro, J.L. and Passos, C.A. (2006) "Desindustrialização: a crônica da servidão consentida", Economia e Tecnologia, Vol. 4: 1-8.

Lynch, M.J. (2020) "Green Criminology and Environmental Crime: Criminology that Matters in the Age of Global Ecological Collapse", Journal of White-Collar and Corporate Crime, 1(1): 50-61.

Lynch, M.J. et al. (2013) "Is it a Crime to Produce Ecological Disorganization?", British Journal of Criminology, Vol. 53: 997-1016.

Lynch, M.J., Long, M.A. and Stretesky, P.B. (2015) “Anthropogenic Development Drives Species to Be Endangered: Capitalism and the Decline of Species", in R.A. Sollund, ed., Green Harms and Crimes: Critical Criminology in a Changing World. New York: Palgrave Macmillan.

Mapbiomas (2020) "Relatório Anual de Desmatamento". Available online at: http://alerta.mapbiomas. orgp (accessed 23 August 2020).

Martín, A.N. (2011) "Bases Para un Futuro Derecho Penal Internacional del Medio Ambiente", Revue internationale de droit penal, 82(3): 477-505.

Martín, A.N., Dopico, J.G.A. and Zapatero, L.A. (2019) “Ecocídio”, El País, 12 December. Available online at: https://www.iustel.com/diario_del_derecho/noticia.asp?ref_iustel=1193512 (accessed 6 September 2020).

Mascaro, C. and Mascaro, P. (2016) "A terra devastada”, Revista Piauí, July. Available online at: https://piaui.folha.uol.com.br/materia/a-terra-devastada/ (accessed 11 February 2021).

Mbembe, A. (2019). Necropolitics. Durham, NC: Duke University Press.

Michalowski, R. (2020) “The Necropolitics of Regulation”, Journal of White-Collar and Corporate Crime, 1(2): 83-5.

Michalowski, R. and Brown, M. (2019) “Old Wine, New Bottles: Contextualizing Trump's Regulatory Rollback”, in Dawn L. Rothe and Victoria E. Collins, eds., Explorations in Critical Criminology in Honor of William J. Chambliss. Leiden and Boston: Brill.

Michalowski, R. and Brown, M. (2020) "Poisoning for Profit: Regulatory Rollbacks, Public Health, and State-Facilitated Corporate Crime", Journal of White Collar and Corporate Crime, 1(2): 113-22.

Ministério Público Federal (2020) "Nota Técnica no 8, de 13 de abril de 2020". Available online at: http://www.mpf.mp.br/pfdc/manifestacoes-pfdc/notas-tecnicas/nota-tecnica-8-2020-pfdc-mpf (accessed 1 February 2021).

Mujtaba, G. and Karam, F.W. (2017) “Monitoring Deforestation Using Remote Sensing”. International Journal of Computer Science and Information Security, 15(1): 75-9.

Novais, F. (1989) Portugal e Brasil na crise do Antigo Sistema Colonial (1777-1808). São Paulo: Hucitec.

OECD (2018) "Trade in Value-Added: Brazil". Available online at: https://www.oecd.org/industry/ ind/TIVA-2018-Brazil.pdf (accessed 17 August 2020).

Oreiro, J.L. and Feijó, C.A. (2010) "Desindustrialização: conceituação, causas, efeitos e o caso brasileiro", Revista de Economia Política, Vol. 30: 219-32.

Patriani L. (2021) “As the Amazon Unravels into Savanna, its Wildlife will Also Suffer”, Mongabay, 10 February. Available online at: https://news.mongabay.com/2021/02/as-the-amazon-unravels-into-savanna-its-wildlife-will-also-suffer/ (accessed 20 August 2021).

Peron, I. (2021) "Ricardo Salles é alvo de operação da PF; presidente do Ibama é afastado", Valor Econômico, 19 May. Available online at: https://valor.globo.com/politica/noticia/2021/05/19/ ricardo-salles-e-ministerio-do-meio-ambiente-sao-alvos-de-busca-e-apreensao-da-pf.ghtml (accessed 20 August 2021).

Pontes, N. (2020) "Fogo já consumiu mais de 10\% do Pantanal em 2020", Deutsche Welle, 10 August. Available online at: https://www.dw.com/pt-br/fogo-j\%C3\%A1-consumiu-mais-de-10-do-pantanal-em-2020/a-54630524 (accessed 20 August 2020). 
Prata, D.A. (2019) Criminalidade corporativa e vitimização ambiental: análise do caso Samarco. São Paulo: LiberArs.

Prata, D.A. (2020) "Corporate Crime and Environmental Victimisation: Analysis of the Samarco Case”, Revue Internationale de Dróit Penal, 91(1): 203-23.

Rajão, R. et al. (2020) “The Brazilian Rotten Apples. Brazil's Inability to Tackle Illegal Deforestation Puts the Future of its Agribusiness at Risk", Science, 369(6501): 246-8.

Repórter Brasil (2021a) “Trabalho escravo na indústria de carne.” Available online at: https://reporterbrasil.org.br/tipos-de-material/publicacoes/ (accessed 22 October 2021).

Repórter Brasil (2021 b) "Café certificado, trabalhador sem direitos." Available online at: https:// reporterbrasil.org.br/tipos-de-material/publicacoes/ (accessed 22 October 2021).

Rodrigues, S. (2019) "Retrospectiva 2019: Após extinguir comitê gestor, governo paralisa Fundo Amazônia", OECO. Available online at: https://www.oeco.org.br/noticias/retrospectiva-2019-aposextinguir-comite-gestor-governo-paralisa-fundo-amazonia (accessed 24 August 2020).

Rose-Ackerman, S. and Pimenta, R.M. (2020) "Corruption in Brazil: Beyond the Criminal Law", in P.F. Lagunes and J. Svejnar, eds., Corruption and the Lava Jato Scandal in Latin America. New York: Routledge Taylor \& Francis Group.

Ruggiero, V. and South, N. (2010) "Critical Criminology and Crimes Against the Environment", Critical Criminology, 18(4): 245-50.

Saad-Diniz, E. (2018) "Brasil v. Golias: os 30 anos da responsabilidade penal da pessoa jurídica e as novas tendências em compliance", Revista dos Tribunais, 988(107): 25-53.

Saad-Diniz, E. (2019a) "Compliance sob a perspectiva da criminologia econômica”, in R.V.B. Cueva and A. Frazão, eds., Compliance: Perspectivas e desafios dos programas de conformidade. Belo Horizonte: Forum.

Saad-Diniz, E. (2019b) "Justicia Restaurativa y desastres socioambientales en Brasil", Revista de Derecho Penal y Criminología Edición Especial, 10: 9-26.

Saad-Diniz, E. (2019c) Vitimologia corporativa. São Paulo: Tirant lo Blanch.

Saad-Diniz, E. (2020) "Vitimização corporativa e dependência comunitária na criminologia ambiental: o acerto de contas com os desastres ambientais", Boletim do Instituto Brasileiro de Ciências Criminais, 27(327): 2-5.

Saad-Diniz, E. and Gianecchini, J.V.P (2020) "The Gears of Environmental Victimization", Revue Internationale de Droit Pénal, Vol. 91: 347-74.

Sakamoto, L. and Casara, M. (2008) “Conexões Sustentáveis São Paulo-Amazônia Quem se beneficia com a destruição da Amazônia”, Repórter Brasil, October. Available at: https://reporterbrasil. org.br/documentos/conexoes_sustentaveis.pdf (accessed 24 August 2020).

Sales, L.P., Galetti, M. and Pires, M.M. (2020) "Climate and Land-Use Change will Lead to a Faunal 'Savannization' on Tropical Rainforests", Global Change Biology, 26(12): 7036-44.

Shukla, J., Nobre, C. and Sellers, P. (1990) “Amazon Deforestation and Climate Change”, Science, 247(4948): 1322-5.

Siegel, D., Spapens, T. and van Uhm, D. (2020) "Regulators and Villains: The Dual Role of Private Actors in Diamonds and Caviar", Crime, Law and Social Change, Vol. 74: 1-15.

Silvério, D.V., Brando, P.M., Balch, J.K., Putz, F.E., Nepstad, D.C., Oliveira-Santos, C. and Bustamante, M.M. (2013) "Testing the Amazon Savannization Hypothesis: Fire Effects on Invasion of a Neotropical Forest by Native Cerrado and Exotic Pasture Grasses", Philosophical Transactions of the Royal Society of London. Series B, Biological Sciences, 368(1619): 1-8.

Simpson, S.S. (2002) Corporate Crime, Law, and Social Control. New York: Cambridge University Press. Simpson, S. (2019) "Reimagining Sutherland 80 Years After White-Collar Crime", Criminology, Vol. 57: 89-207. 
Sollund, R.A. (2015) Green Harms and Crimes: Critical Criminology in a Changing World. New York: Palgrave Macmillan.

Spring, J. (2020) "Brazil Minister Calls for Environmental Deregulation While Public Distracted by COVID”, Reuters, 22 May. Available online at: https://www.reuters.com/article/us-brazil-politicsenvironment/brazil-minister-calls-for-environmental-deregulation-while-public-distracted-bycovid-idUSKBN22Y30Y (accessed 23 August 2020).

Spring, J. and Marcello, M.C. (2020) "Brazil Delays Vote on Land Bill amid Threat of Environmental Boycott”, Reuters, 20 May. Available online at: https://www.reuters.com/article/us-brazil-environment/brazil-delays-vote-on-land-bill-amid-threat-of-environmental-boycott-idUSKBN22W2TU? (accessed 22 August 2020).

Spring, J. and Marcello M.C. (2021) "Brazil Environment Minister Quits; Faces Illegal Logging Probe", Metro International, 24 June. Available online at: https://www.metro.us/brazil-environment-minister-quits/ (accessed 20 July 2021).

Stuckert, R. and Gentilli, P. (2019) Amazonas: Vidas en peligro: Pueblos indigenas de Brasil [Amazon: Lives in Danger: Brazilian Indigenous Peoples]. Buenos Aires: CLACS.

Sunstein, C.R. (2021) “Trump Judges won't be Biden's Highest Legal Hurdle”, Bloomberg, 28 January. Available online at: https://www.bloomberg.com/opinion/articles/2021-01-28/trump-judges-wont-be-biden-s-highest-legal-hurdle (accessed 14 May 2021).

The White House (2021) "Modernizing Regulatory Review", Presidential Actions. Available online at: https://www.whitehouse.gov/briefing-room/presidential-actions/2021/01/20/modernizing-regulatory-review/ (accessed 14 May 2021).

Urban, M. and Saad-Diniz, E. "Why Brazil's COVID-19 Response is Failing", The Regulatory Review. Available online at: https://www.theregreview.org/2020/06/22/urban-saad-diniz-brazil-covid19-response-failing/ (accessed 14 May 2021).

Vale, M.M., Berenguer, E., de Menezes, M.A., de Castro, E.B.V., de Siqueira, L.P. and Rita de Cássia, Q.P. (2021) "The COVID-19 Pandemic as an Opportunity to Weaken Environmental Protection in Brazil", Biological Conservation, Vol. 255: 1-5.

van Sollinge, T.B. (2014) "Researching Illegal Logging and Deforestation", International Journal for Crime, Justice and Social Democracy, 3(2): 35-48.

van Sollinge, T.B. (2017) "Deforestation Crimes and Conflicts in the Amazon", Critical Criminology, 18(4): 205-19.

Vasconcelos, G. and Conceição, A. (2021) "Savanização da Amazônia terá custo incalculável para economia brasileira, diz Levy", Valor, 19 April. Available online at: https://valor.globo.com/live/ noticia/2021/04/19/savanizacao-da-amazonia-tera-custo-incalculavel-para-economia-brasileiradiz-levy.ghtml (accessed 21 April 2021).

Vetlesen, A.J. (2005) Evil and Human Agency: Understanding Collective Evildoing. New York: Cambridge University Press.

White, R. (2008) Crimes Against Nature: Environmental Criminology and Ecological Justice. New York: Willan Publishing.

White, R. (2010a) "Environmental Victims and Resistance to State Crime through Transnational Activism", Social Justice, 36(3): 46-60.

White, R. (2010b) "Globalization and Environmental Harm", in R. White, ed., Global Environmental Harm: Criminological Perspectives. Portland, OR: Willan Publishing, 3-19.

White, R. (2018) "Ecocide and the Carbon Crimes of the Powerful", University of Tasmania Law Review, 37(2): 95-115.

Whyte, D. (2014) "Regimes of Permission and State-Corporate Crime", State Crime Journal, 3(2): 237-46. 
Wyatt, T., South, N. and Beirne, P. (2014) “Introduction: Green Criminology Matters", International Journal for Crime Justice and Social Democracy, 3(2): 1-4.

Zaffaroni, E.R. (2015) "O papel do direito penal e a crise financeira", in E. Saad-Diniz, D. Brodwski and A.L. de Sá, eds., Regulação do abuso no âmbito corporativo: o papel do direito penal na crise financeira. São Paulo: LiberArs.

Zinet, C., Tupinambá, I. and Cabral, M. (2012) “O Massacre do Povo Guarani-Kaiowá” [The Massacre of the Guarani-Kaiowá People], Le Monde Diplomatique Brasil, 4 January. Available online at: https://diplomatique.org.br/o-massacre-do-povo-guarani-kaiowa/ (accessed 23 April 2020). 